\title{
Minęło już pół wieku... Powstanie i działalność Wydawnictwa Naukowego UAM
}

Streszczenie. W roku 2012 Wydawnictwo Naukowe UAM obchodzi 50-lecie istnienia - działa od roku 1962 jako jednostka ogólnouczelniana Uniwersytetu im. Adama Mickiewicza w Poznaniu. Publikuje przede wszystkim monografie naukowe (w 50 seriach tematycznych), podręczniki, skrypty, słowniki, a także 25 czasopism naukowych (również w językach obcych). Rocznie ukazuje się około 150 tytułów. Za swoje osiągnięcia edytorskie wielokrotnie otrzymywaliśmy nagrody, m.in. na Krajowych Targach Książki Akademickiej ATENA, Wrocławskich Targach Książki Naukowej, Nagrody Klio na Targach Książki Historycznej, nagrody Stowarzyszenia Wydawców Szkół Wyższych im. ks. Edwarda Pudełki za najlepszy podręcznik akademicki oraz dyplomy i wyróżnienia w kolejnych edycjach Poznańskiego Przeglądu Nowości Wydawniczych, organizowanego przez Bibliotekę Raczyńskich.

Nasze książki prezentowane były na międzynarodowych wystawach polskiej książki naukowej organizowanych przez Stowarzyszenie Wydawców Szkół Wyższych w: Paryżu, Londynie, Lwowie, Rzymie, Sztokholmie, Wilnie, Pradze, Kijowie, Petersburgu, Dniepropietrowsku, Watykanie, Wiedniu, Madrycie, a także na międzynarodowych targach książki we Frankfurcie, Londynie, Moskwie, Zagrzebiu, Győr (Węgry) i Pekinie.

Wydawnictwo Naukowe UAM jest pomysłodawcą i głównym organizatorem Poznańskich Dni Książki Naukowej, odbywających się nieprzerwanie od 1997 roku i gromadzących wydawców z całej Polski. Miejscem corocznych targów książki jest Hol Wielki Collegium Maius.

Wydawnictwo jest jednym z członków założycieli Stowarzyszenia Wydawców Szkół Wyższych oraz członkiem Polskiego Towarzystwa Wydawców Książek.

SŁowa KLuczowe: Wydawnictwo Naukowe UAM, Poznańskie Dni Książki Naukowej, książka naukowa, wydawnictwa ciągłe, serie wydawnicze, podręcznik akademicki, skrypt, targi książki, promocja książki, kształcenie edytorskie. 
1. Wydawnictwo jako jednostka ogólnouczelniana służy społeczności akademickiej, zarówno pracownikom naukowym, jak i studentom.

2. Wydawnictwo jest placówką integrującą przedstawicieli wszystkich uprawianych na Uczelni dyscyplin naukowych [...].

3. Wydawnictwo uczestniczy [...] w tworzeniu dobrego wizerunku Uczelni i promowaniu jej osiągnięć.

4. Wydawnictwo reprezentuje środowisko uniwersyteckie poprzez jego publikacje ${ }^{1}$.

Tak sformułowane zadania stawiane przed Wydawnictwem uniwersyteckim jasno określają pozycję, jaką zajmuje ono w strukturze uczelni. Od początku powstania Uniwersytetu Poznańskiego jego władze przykładały dużą wagę do działalności wydawniczej. Już w lutym 1920 roku powołana została przez Senat Komisja Wydawnicza UP, która koordynowała publikowanie prac naukowych i poczyniła - uwieńczone sukcesem starania o zapewnienie Uniwersytetowi własnej drukarni. Podczas kadencji rektorskiej Edwarda Lubicz-Niezabitowskiego (1928-1929) nastąpiło ostateczne przekazanie na rzecz uczelni Drukarni Uniwersyteckiej, w drodze aktu darowizny od Józefa Winiewicza ${ }^{2}$. W latach powojennych znów powróciła sprawa odzyskania drukarni zabranej Uniwersytetowi w 1951 roku. W działania te zaangażował się bardzo mocno rektor Alfons Klafkowski. „Uniwersytet nie może rozwijać się naukowo - mówił w przemówieniu inauguracyjnym w 1957 roku - bez możliwości druku”3.3. Ostatecznie drukarnia stała się integralną częścią Uniwersytetu w czasie drugiej kadencji rektorskiej Alfonsa Klafkowskiego.

Po wojnie pierwszą zorganizowaną komórką wydawniczą była Redakcja Zeszytów Naukowych (1955-1958). Działała ona w składzie: prof. dr Tadeusz Cyprian - redaktor naczelny, prof. dr Marian Zimmermann - redaktor Wydziału Prawa, prof. dr Janusz Deresiewicz - redaktor Wydziału Filozoficzno-Historycznego, prof. dr Andrzej Alexiewicz redaktor Wydziału Matematyki, Fizyki i Chemii, doc. dr Jerzy Ziomek redaktor Wydziału Filologicznego, mgr Tadeusz Klanowski - sekretarz Redakcji. 1 stycznia 1958 roku utworzono jednostkę administracyjną Sekcję Wydawnictw, którą kierowała Maria Bossowska, a następnie Dział

${ }^{1}$ Dokumenty archiwalne Wydawnictwa niedatowane, prawdopodobnie z początku lat 90., związane z przygotowywaniem regulaminu. Całość zapisu określającego rolę i zadania Wydawnictwa zawiera załącznik 1.

2 A. Dzięczkowski, Edward Lubicz-Niezabitowski (1928-1929), w: Poczet rektorów Almae Matris Posnaniensis, red. T. Schramm, Poznań 2004, s. 70.

${ }^{3}$ H. Olszewski, Alfons Klafkowski (1956-1962), w: Poczet rektorów..., s. 193. 
Wydawnictw - redaktorem naczelnym był nadal prof. dr Tadeusz Cyprian. W tym roku, oprócz Zeszytów Naukowych, wznowiono publikowanie Kroniki Uniwersyteckiej. Do tych zadań powołano specjalną redakcję - prof. dr Janusz Deresiewicz pełnił funkcję redaktora, a sekretarzem został dr Adam Łopatka. Zespół ten przygotował do druku Kroniki UAM za lata 1945-1954/55, 1955/1956, 1956/1957. Kolejne tomy obejmujące okres 1957/1958 oraz 1958/1959 opracował dr Adam Łopatka. Ponadto w 1958 roku rozpoczęto wydawanie Biuletynu Biblioteki Głównej UAM. Rok 1958 był również ważny ze względu na utworzenie własnej bazy poligraficznej - Uniwersytet otrzymał z fundacji Forda maszyny do powielania Vari Typer, Electro Rex i Rex Rotary, co pozwoliło na uruchomienie Powielarni UAM ${ }^{4}$.

W styczniu 1959 roku powołano Tymczasowy Komitet Redakcyjny Wydawnictw UAM w składzie: doc. dr Józef Kwiatek - redaktor naczelny, doc. dr Wiktor Jaśkiewicz - redaktor Wydziału Prawa, zast. prof. dr Władysław Markiewicz - redaktor Wydziału Filozoficzno-Historycznego, doc. dr Stanisław Gniadek - redaktor Wydziału Filologicznego, doc. dr Wacław Wójciak - redaktor Wydziału Matematyki, Fizyki i Chemii, prof. dr Florian Barciński - redaktor Wydziału Biologii i Nauk o Ziemi, dyr. dr Stanisław Kubiak - redaktor Biblioteki Głównej, mgr Tadeusz Klanowski - sekretarz Redakcji ${ }^{5}$.

Tymczasowy Komitet Redakcyjny zorganizował Wydawnictwo UAM. Wkrótce podjął decyzję (1959) o rozszerzeniu działalności wydawniczej na prace habilitacyjne, doktorskie oraz skrypty. Nadal kontynuowano wydawanie Zeszytów Naukowych i Kroniki UAM. W listopadzie 1960 roku, po ustąpieniu Tymczasowego Komitetu Redakcyjnego, nastąpiła reorganizacja Wydawnictwa. Powołano nowy Komitet Redakcyjny, na którego czele stanął prof. dr Czesław Łuczak. Zastępcą redaktora naczelnego został prof. dr Wacław Wójciak, a sekretarzem Redakcji dr Benon Miśkiewicz 6 .

Nowe zadania wymagały jednak stworzenia wyspecjalizowanej placówki, toteż w 1960 roku rozpoczęto organizowanie Redakcji Naukowo-Technicznej. Powierzenie w 1962 roku jej kierownictwa doświadczonej w zakresie edytorstwa naukowego mgr Wandzie Serwańskiej zapewniło

${ }^{4}$ Kronika UAM za lata akad. 1959/62, Poznań 1963, s. 457.

${ }^{5}$ Archiwum UAM: Protokoły Senatu 1958/59. Protokół z IV zwyczajnego posiedzenia Senatu Akademickiego UAM, które odbyło się w dniu 5 stycznia 1959 roku. Komunikaty.

${ }^{6}$ Archiwum UAM: Protokoły Senatu 1960/61. Protokół z IV zwyczajnego posiedzenia Senatu Akademickiego, które odbyło się w dniu 7 listopada 1960 roku, pkt VI. 
kształtującemu się Wydawnictwu profesjonalne podstawy. Pod jej kierunkiem fachowe przygotowanie zdobywali przyjmowani pracownicy (m.in. przyszli dyrektorzy i kierownicy redakcji). Obok Redakcji Naukowo-Technicznej funkcjonował jednoosobowy Dział Wydawnictw, zajmujący się zagadnieniami finansowymi i administracyjnymi. W tym samym roku Wydawnictwo otrzymało status jednostki ogólnouniwersyteckiej.

O poziom naukowy publikacji, prowadzenie polityki wydawniczej zgodnie z potrzebami Uniwersytetu oraz o możliwości rozwoju etatowego i produkcji wydawniczej dbał Komitet Redakcyjny. Jego przewodniczącym w latach 1960-1981 był prof. dr Czesław Łuczak.

Oczkiem w głowie rektora Łuczaka było Wydawnictwo Naukowe UAM, które w czasie jego kadencji stało się najprężniejszym i największym tego typu w Polsce, Drukarnia Uniwersytecka natomiast najlepiej wyspecjalizowaną placówką w kraju. Posiadał Profesor umiejętności wyjednywania środków na publikacje naukowe, dbał o rozwój Wydawnictwa ${ }^{7}$

- pisała w biogramie rektora Aleksandra Kosicka-Pajewska.

Lata 70. były okresem ukształtowania się struktury organizacyjnej Wydawnictwa (od 1972 roku działa ono pod nazwą Wydawnictwo Naukowe UAM), powiększenia i stabilizacji zespołu, znacznego wzrostu liczby wydawanych arkuszy, unowocześnienia i uatrakcyjnienia szaty graficznej. Duże zasługi w tym zakresie położył prof. dr hab. Jerzy Wisłocki - ówczesny sekretarz Komitetu Redakcyjnego. Powiększenie zespołu (przyjęto pięciu nowych pracowników) wiązało się z powstaniem nowej Redakcji Wydawnictw Dydaktycznych i Informacyjnych (kierownik mgr Wojciech Wolarski) i tymczasowym ulokowaniem jej w gmachu PTPN przy ul. Mielżyńskiego 27/29. Główna siedziba Wydawnictwa nadal znajdowała się przy ul. Słowackiego $20^{8}$, gdzie urzędowała redaktor naczelna mgr Wanda Serwańska, odbywały się spotkania Komitetu Redakcyjnego, działały wcześniej istniejące redakcje: Wydawnictw Humanistycznych (kierownik mgr Maria Zawiejska-Jankowska, zespół: osiem osób), Wydawnictw Przyrodniczych (kierownik mgr Krystyna Plucińska, zespół: cztery osoby) i mieścił się Dział Administracyjno-Handlowy

${ }^{7}$ A. Kosicka-Pajewska, Czesław Euczak (1965-1972), w: Poczet rektorów..., s. 216.

${ }^{8}$ Kolejny adres to ul. Marchlewskiego 128 (obecnie al. Niepodległości), gdzie pod koniec roku 1982 Wydawnictwo wprowadziło się na VII piętro gmachu "Miastoprojektu”. W 1990 roku oficynę ulokowano w willi przy ul. Nowowiejskiego 55, a po 20 latach, w maju 2010 roku Wydawnictwo przeniesiono na IV piętro Collegium Maius (ul. Fredry 10). 
(kierownik Maria Szeszułowa, zespół: dwie osoby). W 1975 roku w Wydawnictwie Naukowym UAM pracowały 23 osoby.

W tym czasie nastąpiła również modernizacja Zakładu Graficznego, który obok Drukarni UAM stanowił bazę poligraficzną Wydawnictwa. Wtedy też powstał podstawowy zrąb serii wydawniczych i wypracowano model wydawnictw ciągłych'.

Wydawnictwo Naukowe UAM stało się jednym z największych i najlepiej działających wydawnictw uczelnianych w kraju. Zwiększył się również stan osobowy - w roku 1979 pracowało 28 osób - rozszerzono Dział Administracyjno-Ekonomiczny (do sześciu osób) i utworzono Redakcję Techniczną (trzy osoby), która dbała o profesjonalny poziom opracowania edytorskiego. Jej działania wspierał doświadczony redaktor techniczny Michał Łyssowski, który przeszedł do oficyny UAM z Ossolineum. W kolejnych latach liczba pracowników utrzymywała się mniej więcej na tym samym poziomie. Zmniejszenie zatrudnienia nastąpiło dopiero po 2000 roku $^{10}$. Ewolucji ulegała także struktura jednostki, np. w latach 80 . z Redakcji Wydawnictw Humanistycznych wyodrębniono Redakcje Nauk Filologicznych (kierownik mgr Maria Zawiejska-Jankowska) oraz Redakcję Nauk Historycznych i Społecznych (kierownik mgr Danuta Kawczyńska). Nadal działała Redakcja Nauk Przyrodniczych (kierownik mgr Aleksandra Jędrzejczak). W 1986 roku utworzono stanowisko sekretarza Wydawnictwa (objęła je mgr inż. Ewa Przymusińska) oraz przystąpiono do kompletowania Działu Składu Komputerowego, który w pełnej obsadzie (siedem osób) rozpoczął pracę w 1990 roku.

Wszelkie zmiany strukturalne, osobowe, innowacyjne (np. wprowadzanie nowych technik druku) wiązały się ściśle z podniesieniem jakości wydawanych książek i zwiększeniem produkcji. Warto przypomnieć, że w latach 70. Wydawnictwo, na podstawie zgłoszeń z uczelni, zgodnie $\mathrm{z}$ wydawanymi corocznie szczegółowymi wytycznymi ministerstwa opracowywało projekt uczelnianego planu wydawniczego, który musiał być zaopiniowany przez Kolegium Rektorskie. Plan wydawniczy zatwierdzał ostatecznie minister nauki, szkolnictwa wyższego i techniki. Zatwierdzeniu przez ministerstwo podlegały następujące elementy planu: tytuł publikacji, objętość w arkuszach, nakład i technika druku. Od 1972 roku decyzję dotyczącą techniki

${ }^{9}$ Pełen wykaz serii wydawniczych podano w załączniku 2, natomiast wydawnictwa ciągłe (czasopisma) zostały ujęte w załączniku 3.

10 Stan zatrudnienia w Wydawnictwie $\mathrm{w}$ wybranych przykładowo latach przedstawiał się następująco: 1959/60 - 4 osoby, 1968/69 - 8, 1975/76 - 23, 1978/79 - 28, 1985/86 - 26, 1991/92 - 28, 1993/94 - 27, 1995/96 - 26, 2000/2001 - 24, 2002/2003 - 23, 2005/2006 - 22, 2009/2010 - 24, $2011-20,2012-20$. 
druku podejmował rektor ${ }^{11}$. Podstawowym kryterium decydującym o rozmiarach działalności Wydawnictwa był ustalany corocznie limit na cele wydawnicze. Do roku 1973 włącznie decydowało o tym ministerstwo, od roku 1974 kompetencje te powierzono rektorom. W latach 1968-1973 budżet Wydawnictwa oscylował w granicach od $2 \mathrm{mln}$ do 2,7 mln zł, w roku 1974 wzrósł do 3,5 mln zł. Kwota ta wystarczała na realizację zaledwie części potrzeb wydawniczych ${ }^{12}$. Sytuacja pogorszyła się jeszcze w 1972 roku w związku z podwyższeniem ceny papieru i usług poligraficznych o ponad $40 \%$. Wzrastała dysproporcja między liczbą zgłaszanych do druku arkuszy a możliwościami produkcyjnymi Wydawnictwa. Uwzględniając te trudności, Komisja Senacka ds. Wydawniczych ustaliła następujący priorytet druku: 1) wszystkie periodyki, 2) wszystkie rozprawy habilitacyjne, 3) wszystkie materiały z sesji naukowych organizowanych przez UAM, 4) niezbędne skrypty i pomoce dydaktyczne, 5) w miarę rezerw finansowych inne prace naukowe. Zgodnie $\mathrm{z}$ wytycznymi ministerstwa druk prac ze względów oszczędnościowych realizowano w większości techniką małej poligrafii. Zgodnie z zaleceniami władz partyjnych (uchwała Egzekutywy KU PZPR z 1973 roku) Wydawnictwo rozbudowało możliwości produkcyjne na rok 1975 do 1000 arkuszy $^{13}$. W związku z podanymi wyżej uwarunkowaniami osiągnięcie tego pułapu wydawało się szczytem możliwości. Jednak dzięki ofiarnej pracy całego zespołu ten ambitny plan został zrealizowany - w roku 1975 po raz pierwszy przekroczono liczbę 1000 arkuszy wydawniczych (dla porównania, w roku 1968 opublikowano 530 arkuszy, a w 1971 - 706 arkuszy) $)^{14}$.

Po przejściu Wandy Serwańskiej, pełniącej funkcję naczelnego redaktora Wydawnictwa, na emeryturę (w czerwcu 1980 roku) na stanowisko dyrektora placówki powołany został mgr Wojciech Wolarski. W związku z jego rezygnacją z pracy na uczelni w 1991 roku pełnienie obowiązków dyrektora powierzono mgr Ewie Bosackiej. W 1992 roku również ona zdecydowała się zmienić pracę i obowiązki te od czerwca 1992 roku przejęła mgr Maria Zawiejska-Jankowska, dotychczasowa kierowniczka Redakcji

${ }^{11}$ C. Łuczak, Wydawnictwo Naukowe Uniwersytetu im. Adama Mickiewicza w Poznaniu, materiały powielone, Poznań 1974, s. 1.

${ }^{12}$ Ibidem, s. 2.

${ }^{13}$ Ibidem, s. 7.

${ }^{14}$ Kolejne lata przyniosły znaczący wzrost produkcji, np. w 1976 roku wydano 1300 ark., w 1988 - 1100 ark., w 2003 - 1570 ark., w 2004 roku przekroczono 2000 ark., w 2005 - 2103 ark., w 2006 - 2279 ark. Rekordowy był rok 2009, kiedy opublikowano 149 książek o łącznej objętości 2791 ark. W kolejnych latach produkcja ustabilizowała się na poziomie powyżej 2200 ark. (2010 rok - 2214 ark., 2011 rok - 2296 ark.). 
Nauk Filologicznych. W wyniku ogłoszonego przez rektora konkursu na stanowisko dyrektora Wydawnictwa otrzymała ona formalną nominację (od 1 lutego 1994 roku). Utworzono zarazem stanowisko zastępcy dyrektora, ukierunkowane przede wszystkim na działania marketingowe i promocyjne. Funkcję tę powierzono w 1993 roku mgr Iwonie Wegner-Maruszewskiej (również uczestniczącej w konkursie na dyrektora). Nominacje wpłynęły na zmiany organizacyjne $\mathrm{w}$ Wydawnictwie, m.in. na zmniejszenie liczby redakcji merytorycznych ${ }^{15}$.

W 2012 roku zespół Wydawnictwa, liczący 20 osób, stanowili: p.o. dyrektora, sekretarz, siedmiu redaktorów (łącznie z kierownikiem Redakcji Merytorycznej), jeden korektor, dwóch redaktorów technicznych (w tym kierownik Redakcji Technicznej, sprawujący również funkcję inspektora produkcji). W strukturze Wydawnictwa mieści się trzyosobowy Dział Składu Komputerowego oraz Dział Promocji i Sprzedaży (trzy osoby). Nad sprawami finansowymi czuwa samodzielna księgowa, sekretariat prowadzi samodzielny referent. Większość pracowników to osoby z długoletnim stażem zawodowym i doświadczeniem wydawniczym.

Wydawnictwo Naukowe UAM jest jednostką ogólnouczelnianą podległą rektorowi, który bezpośrednie zwierzchnictwo powierza jednemu z prorektorów. Polityka wydawnicza i zatwierdzanie prac do publikacji leżą w gestii Rady Wydawniczejej, ${ }^{16}$ która skupia przedstawicieli wszystkich wydziałów ${ }^{17}$. Jej obecnym przewodniczącym (od 2008 roku) jest prof. dr hab. Jacek Witkoś.

Wydawnictwo publikuje przede wszystkim podręczniki, skrypty oraz monografie z wielu dziedzin wiedzy (w 50 seriach tematycznych), a także 25 czasopism naukowych (również w językach obcych). Są to tytuły w znacznej części niskonakładowe. W ostatnich latach produkcja

${ }^{15}$ W 2002 roku podział strukturalny Wydawnictwa przedstawiał się następująco: Redakcja Merytoryczna (10 osób), Redakcja Techniczna (3 osoby), Dział Składu Komputerowego (3 osoby), Dział Promocji i Sprzedaży (2 osoby), Dział Administracyjno-Ekonomiczny (4 osoby).

16 Dotychczasowi przewodniczący Rady Wydawniczej w układzie chronologicznym: 1960-1981 prof. Czesław Łuczak, 1981-1984 prof. Jacek Fisiak, 1984-1985 prof. Zbyszko Chojnicki, 1985-1990 prof. Andrzej Szwarc, 1991-1993 prof. Jan Strzałko, 1993-1996 prof. Sylwester Dworacki, 1996-1999 prof. Przemysław Hauser, 2000-2005 prof. Bronisław Marciniak, 2005-2008 prof. Sławomira Wronkowska-Jaśkiewicz.

17 Reprezentanci niektórych wydziałów zapisali się wieloletnia, owocną pracą w tym gremium. Do takich osób należą m.in.: prof. Maciej Błaszak (Wydział Fizyki), prof. Andrzej Burewicz (Wydział Chemii), prof. Stefan H. Kaszyński (Wydział Neofilologii), prof. Roman Murawski (Wydział Matematyki i Informatyki), prof. Janusz Piontek (Wydział Biologii), prof. Krzysztof Pietkiewicz (Wydział Historyczny), prof. Alojzy Woś (Wydział Nauk Geograficznych i Geologicznych). 
ustabilizowała się - rocznie ukazuje się około 120-130 pozycji o łącznej objętości około 2100-2300 arkuszy wydawniczych, co stawia Wydawnictwo w czołówce oficyn uczelnianych.

Wśród periodyków naukowych przeważają czasopisma humanistyczne. Wiele tytułów poświęconych jest specjalistycznej tematyce, np. z zakresu historii sztuki - „Artium Quaestiones”, nauk językoznawczych "Glottodidactica”, „Linguistic and Oriental Studies from Poznan”, ,Studia Phonetica Posnaniensia”, nauk socjologicznych - „Człowiek i Społeczeństwo", "Roczniki Socjologii Rodziny”, pedagogicznych - "Studia Edukacyjne”, „Neodidagmata”, neofilologii - „Studia Romanica Posnaniensia”, „Studia Rossica Posnaniensia”, interdyscyplinarne „Polish Anglo-Saxon Studies", poświęcone teorii literatury "Przestrzenie Teorii” oraz zagadnieniom filmoznawczym - „Images” i muzykologicznym „Interdisciplinary Studies in Musicology”. Publikujemy też od wielu lat cenny periodyk "Functiones et Approximatio Commentarii Mathematici", przygotowywany na Wydziale Matematyki i Informatyki. Najdłużej wydawanym czasopismem był kwartalnik „Ruch Prawniczy, Ekonomiczny i Socjologiczny", który ukazywał się ponad 60 lat.

Do innych szczególnie pieczołowicie przygotowywanych publikacji należą pozycje związane $z$ historią i obchodami jubileuszowymi naszego Uniwersytetu. Wśród nich znajdują się m.in.: praca zbiorowa pod red. Zofii Trojanowiczowej i Zbigniewa Przychodniaka - Księga Mickiewiczowska. Patronowi Uczelni w dwusetna rocznice urodzin (1998), Alma Mater Posnaniensis. W 80. rocznice utworzenia Uniwersytetu w Poznaniu pod red. Przemysława Hausera, Tomasza Jasińskiego i Jerzego Topolskiego (1999), Zygmunta Borasa Tradycje uniwersyteckie Poznania (2003), W hotdzie naszym antenatom. 85 lat Uniwersytetu im. Adama Mickiewicza pod red. Jerzego Laskowskiego i Grzegorza Łukomskiego (2004), Poczet rektorów Almae Matris Posnaniensis pod red. Tomasza Schramma i Anny Marciniak (2004) czy album Uniwersytet im. Adama Mickiewicza z fotografiami Stanisława Ossowskiego i Kazimierza Frysia, w wersji polsko-angielskiej, wydany z okazji 85-lecia UAM (2004). W związku z obchodami 400-lecia Uniwersytetu w 2011 roku ukazały się okolicznościowe publikacje: Wokót Jezuickiej Fundacji Uniwersytetu z 1611 roku pod red. Doroty Żołądź-Strzelczyk i Rafała Witkowskiego oraz Wspomnienia z mej pracy w Biurze Szyfrów Oddziału II Sztabu Głównego w latach 1930-1945 Mariana Rejewskiego (wersja polska i tłumaczenie na język angielski), w opracowaniu Magdaleny Jaroszewskiej.

Istotne miejsce $\mathrm{w}$ dorobku Wydawnictwa zajmują księgi pamiątkowe dedykowane znakomitym uczonym, zasłużonym profesorom Uniwersytetu. W tym gronie znaleźli się m.in.: Jerzy Bańczerowski, Tadeusz 
Batóg i Maria Steffen-Batogowa, Seweryn Dziamski, Ulrich Engel, Jacek Fisiak, Przemysław Hauser, Jan Hellwig, Stefan Kaszyński, Leon Leja, Roman Murawski, Gerard Labuda, Janusz Pajewski, Waldemar Pfeiffer, Stanisław Sołtysiński, Ryszard Stachowski, Andrzej J. Szwarc, Zofia Trojanowiczowa, Ludwik Zabrocki, Krystyna Zamiara, Tadeusz Zdancewicz.

Do ważnych przedsięwzięć wydawniczych ostatnich lat należy nowe krytyczne wydanie Wierszy (2005) i Poematów (t. I i II, 2009) Juliusza Słowackiego, w opracowaniu Zbigniewa Przychodniaka i Jacka Brzozowskiego. Bardzo starannie, często w pięknej szacie graficznej wydawane są liczne rozprawy habilitacyjne, które reprezentują różne dyscypliny uniwersyteckie. Znaczną część produkcji stanowią podręczniki, skrypty i pomoce dydaktyczne. Do najlepiej sprzedających się podręczników akademickich, które osiągnęły kilkutysięczne nakłady i które wielokrotnie wznawiano, należą m.in.: Historia powszechna 1939-1999 Antoniego Czubińskiego i Wiesława Olszewskiego, Pedagogika specjalna pod red. Władysława Dykcika, Metodyka pracy archiwalnej pod red. Stanisława Nawrockiego i Stanisława Sierpowskiego, Analiza matematyczna (t. I i II) Juliana i Heleny Musielaków, Vademecum logopedyczne Krystyny Błachnio, Fizjologia roślin Alicji Szweykowskiej, Podstawy logiki Tadeusza Batoga, Filozofia matematyki. Antologia tekstów klasycznych Romana Murawskiego, Analiza matematyczna Andrzeja Sołtysiaka, Filozofia nauki Jana Sucha i Małgorzaty Szcześniak czy ostatnio wydane po raz trzeci w wersji poszerzonej (2011) Ttumaczenie jako „wojna światów”. W kręgu translatologii $i$ komparatystyki Edwarda Balcerzana.

Wydawnictwo od wielu lat publikuje też cenne słowniki. Wymienić tu można następujące tytuły: Czesław Kudzinowski, Słownik fińsko-polski (t. I i II, 1988), Jerzy Łacina, Słownik arabsko-polski (1997), Jacek Pleciński, Dicionário idiomático português-polaco, Portugalsko-polski słownik frazeologiczny (1999), Sława Awedykowa, Grete Jønsberg, Monika Lande, Halina Zgółkowa, Słownik minimum polsko-norweski z indeksem norwesko-polskim (wyd. 2 - 2001), Sirkka Ojaniemi, Halina Zgółkowa, Słownik minimum polsko-fiński z indeksem fińsko-polskim (1999), Stanisław J. Bartoszek, Mały słownik islandzko-polski, polsko-islandzki (wyd. 4 popr. i uzup. - 2011), seria tematycznych słowników rosyjsko-polskich Antoniego Markunasa i współpracowników czy wydany w 2010 roku na płycie CD Supersłownik hebrajsko-polski z indeksem polsko-hebrajskim autorstwa Liory Weinbach i Edny Lauden, w tłumaczeniu Miriam Borenstein (ze ścieżką dźwiękową), zawierający 50 tysięcy haseł.

Dyrekcja i zespół Wydawnictwa przykładają wielką wagę do poziomu edytorskiego publikacji, co z pewnością przyczyniło się do sukcesów - za piękne edytorsko i wartościowe książki oficyna otrzymała liczne 
nagrody i wyróżnienia. Pierwsze sukcesy w tej dziedzinie to: nagroda specjalna Ministra Edukacji Narodowej za Dydaktykę chemii Andrzeja Burewicza i Hanny Gulińskiej na I Krajowych Targach Książki Akademickiej ATENA '94 w Warszawie (fot. 1), I nagroda za Chemiczne metody analizy jakościowej Floriana Domki na I Wrocławskich Targach Książki Naukowej (1995) oraz wyróżnienie specjalne za Przemoc na ekranie pod red. Małgorzaty Hendrykowskiej i Marka Hendrykowskiego na IV Wrocławskich Targach Książki Naukowej (1998). Ostatnio publikacje Wydawnictwa Naukowego - Fenomen pięknego życia pod red. Małgorzaty Jankowskiej i Sergiusza Nizińskiego oraz Język - mistyka - proroctwo Alicji Sakaguchi zostały uhonorowane wyróżnieniem Stowarzyszenia Wydawców Katolickich Feniks 2012 na XVIII Targach Wydawców Katolickich ${ }^{18}$.

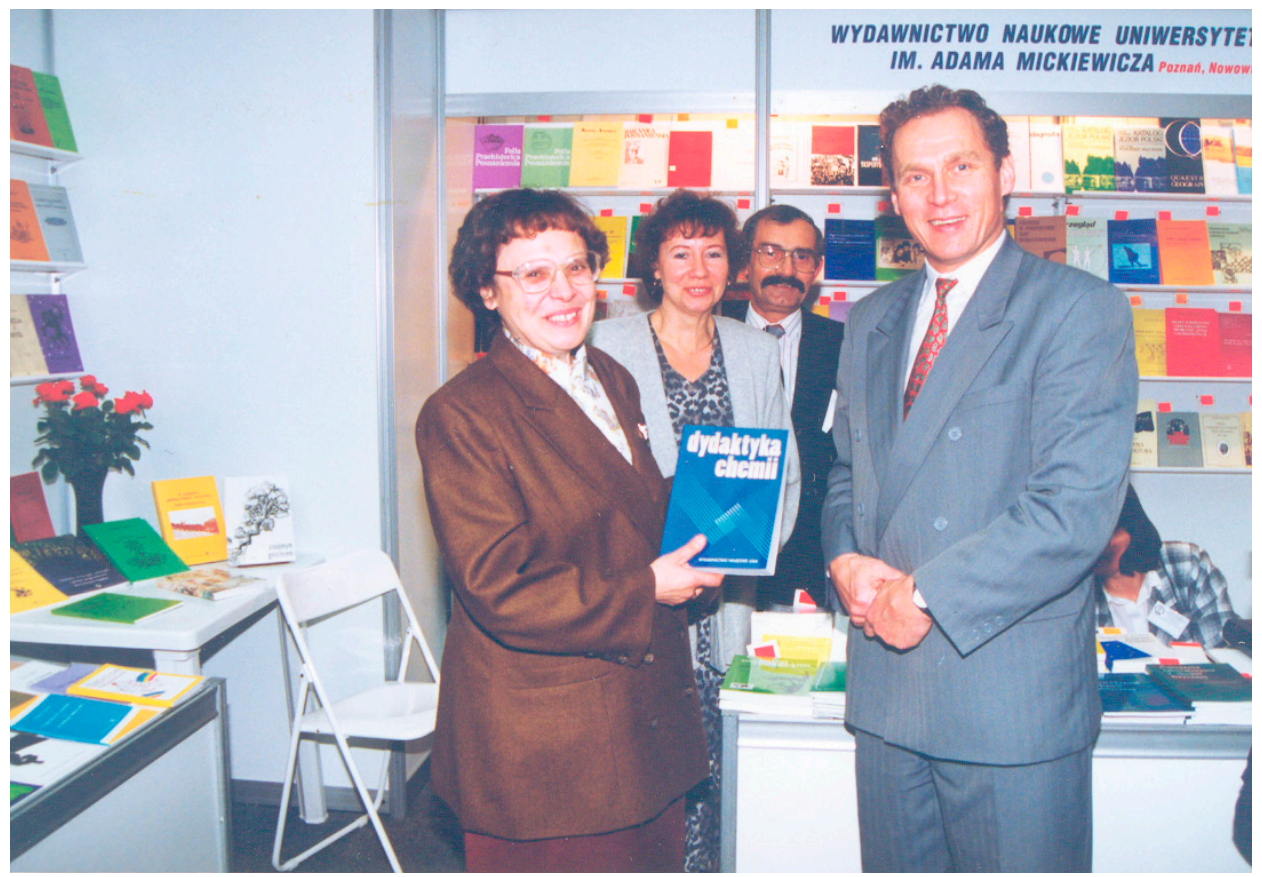

Fot. 1. Targi Atena '94 - nagrodę specjalną Ministra Edukacji Narodowej (z prawej) odbiera dyrektor Wydawnictwa Maria Zawiejska-Jankowska (z lewej). Fot. ze zbiorów prywatnych

Warto też wspomnieć o aktywnych działaniach w środowisku wydawniczym, podejmowanych przez naszą oficynę. Wydawnictwo Naukowe

18 Wykaz nagród i wyróżnień otrzymanych w latach 1994-2012 zawiera załącznik 3. 
UAM jest współzałożycielem i członkiem Stowarzyszenia Wydawców Szkół Wyższych (SWSW) od 1994 roku, a dyrektor Iwona Wegner-Maruszewska przez wiele lat pełniła różne funkcje w Zarządzie Stowarzyszenia. Do tradycji SWSW należą spotkania dyrektorów i redaktorów naczelnych na ogólnopolskich konferencjach wydawców, na których zawsze reprezentowane było Wydawnictwo UAM. Nie do przecenienia jest również wkład Wydawnictwa w kształcenie edytorskie - Iwona Wegner-Maruszewska w okresie 1994-2007 prowadziła zajęcia dla studentów, którzy wybrali specjalizację wydawniczą na filologii polskiej (na studiach dziennych, zaocznych i podyplomowych) oraz kierowała przez 19 lat praktykami studenckimi w Wydawnictwie (około 4-8 osób rocznie) i opiekowała się nowo przyjętymi pracownikami, kształcąc liczne grono młodych edytorów.

Przez wszystkie lata działalności Wydawnictwo prowadzi nieprzerwanie sprzedaż publikacji własnych, w szerokim zakresie także wysyłkową (również za granicę) ${ }^{19}$, w kolejnych swoich siedzibach i na terenie Poznania w Księgarni Uniwersyteckiej (ul. Zwierzyniecka 7) oraz w Poznańskiej Księgarni Akademickiej (ul. Fredry 10). Utrzymuje też kontakty z około 400 księgarniami i hurtowniami na terenie Polski, stara się rozwijać sprzedaż przez organizowanie promocji, udział w targach książki naukowej (uczestniczymy w najważniejszych imprezach targowych tego rodzaju w Polsce), sprzedaż przy okazji konferencji naukowych itp.

Od początku lat 90. Wydawnictwo znacznie rozszerzyło działalność marketingową i promocyjną, m.in. rozwijając własną stronę internetową, a zwłaszcza działy informacyjny, katalogowy oraz handlowy - od roku 2000 działa e-księgarnia. W roku 2011 nastąpiła gruntowna zmiana layoutu strony WWW, rozbudowano menu, stworzono indeks wielokontekstowy, wprowadzono informacje o wersjach elektronicznych książek, które zamieszczane są np. na platformie uniwersyteckiej AMUR, na PWN-owskim IBUK-u. A na portalu księgarskim www.ksiazka.net, portalu teatralnym „Prospero”. Cyklicznie ukazywały się recenzje książek w naukowych, specjalistycznych czasopismach, informacje o nowych tytułach i reklamy w prasie, wywiady $\mathrm{w}$ radiu, prezentacje $\mathrm{w}$ telewizji. Obecność naszych książek w przestrzeni miejskiej Poznania zapewniała współpraca z CK Zamek, księgarnią Bookarest (Stary Browar), Galerią TAK, Poznańskim Towarzystwem Przyjaciół Nauk, Muzeum Archeologicznym, Biblioteką Raczyńskich i Biblioteką Uniwersytecką.

${ }^{19}$ Po roku 2000 sprzedaż wysyłkowa systematycznie wzrastała, np. w 2002 roku w tym systemie sprzedano książki za sumę 20632 zł, w 2003 - za 28712 zł, w 2004 za 32022 zł, w 2005 - za 33615 zł. 
Przybliżeniu książki czytelnikowi służyły promocje nowości i spotkania z autorami, organizowane zarówno w Poznaniu, jak i w innych miastach Polski - Warszawie, Krakowie, Szczecinie, Bydgoszczy, Gnieźnie, Gorzowie Wlkp., Rzeszowie czy też za granicą - ekspozycje na międzynarodowych targach książki i wystawach przygotowywanych przez SWSW.

Na zaproszenie Wydawnictwa przyjeżdżali do Polski zagraniczni autorzy, np. 20 maja 1998 roku odbyła się w Collegium Historicum promocja Dziejów biblijnego Izraela, z udziałem autora André Lemaire'a. Z kolei na VI Poznańskich Dniach Książki Naukowej (PDKN) w CK Zamek zaprezentowano Stulecie Przybosia pod red. Stanisława Balbusa i Edwarda Balcerzana (3 października 2002). W Sali Kominkowej zgromadziło się liczne grono miłośników wierszy Juliana Przybosia. Wydarzenie uświetniły swą obecnością córki poety - Uta i Wanda. Podobne spotkanie odbyło się podczas krakowskich targów książki - zorganizowano je na Uniwersytecie Jagiellońskim. Dużym wydarzeniem była promocja monumentalnej Historii Chorwacji Dragutina Pavličevicia, połączona z wykładem ambasadora Republiki Chorwacji w Polsce prof. Nebojšy Koharovicia, spotkaniem z autorem i tłumaczką Łucją Danielewską 18 maja 2004 roku w Sali Lubrańskiego w Collegium Maius w Poznaniu. Powtórzono ją następnego dnia w Domu Literatury w Warszawie, podczas 49. Międzynarodowych Targów Książki. Również w ramach tych targów w sali Pałacu Kultury i Nauki przedstawiono wyjątkowy album Poland is Not Yet Lost: Heroic and Tragic Tales for the Polish Diaspora i jego autora prof. Christophera Wheatleya z USA. Z kolei gościem IX PDKN był prof. Ferdinand Fellmann, autor książki Para. Erotyczne źródła człowieczeństwa (tłum. Jakub Duraj, Wiesław Małecki, red. nauk. Andrzej Przyłębski). Niewątpliwym wydarzeniem, o czym świadczyła wypełniona po brzegi Sala Lubrańskiego w Collegium Maius, było spotkanie z Rolfem Fieguthem, znakomitym tłumaczem literatury polskiej, i jego książką Gombrowicz $z$ niemiecka gęba $i$ inne studia komparatystyczne (28 marca 2011). Od wielu lat liczba promocji organizowanych przez Wydawnictwo wynosi około 10-12 rocznie.

W 1997 roku Wydawnictwo samo postanowiło zadebiutować jako organizator targów książki, zachęcone przez środowisko wydawców. Inicjatorką tego przedsięwzięcia była ówczesna wicedyrektor Wydawnictwa Iwona Wegner-Maruszewska. Pomysł spotkał się z przychylnością władz uczelni, a zwłaszcza prorektora prof. Przemysława Hausera, który pełnił wtedy funkcję przewodniczącego Rady Wydawniczej. W dniach 8-11 października 1997 roku w holu Collegium Maius odbyły się zorganizowane pod patronatem JM Rektora Uniwersytetu im. Adama Mickiewicza 
prof. dr. hab. Stefana Jurgi pierwsze Poznańskie Dni Książki Naukowej ${ }^{20}$. Inicjatorem i głównym organizatorem imprezy targowej było Wydawnictwo Naukowe UAM, wspierane przez Wielkopolski Oddział Polskiej Izby Książki, Polskie Towarzystwo Wydawców Książek, Biuro Marketingowe „Megaron” oraz Poznański Dom Książki SA. Na czele Komitetu Organizacyjnego stanął prorektor UAM prof. dr hab. Przemysław Hauser, funkcję wiceprzewodniczącej pełniła wicedyrektor Iwona Wegner-Maruszewska z Wydawnictwa Naukowego UAM, a sekretarza - Olcha Sikorska reprezentująca Polską Izbę Książki i Polskie Towarzystwo Wydawców Książek. Była to pierwsza tak duża prezentacja i zarazem promocja wydawnictw specjalizujących się w wydawaniu literatury naukowej i dydaktycznej zorganizowana w Poznaniu. W ofercie handlowej dominowały książki ściśle naukowe oraz podręczniki akademickie, prezentowano ponadto słowniki, leksykony, encyklopedie, pozycje popularnonaukowe, a także literaturę piękną. Targi okazały się dużym sukcesem organizatorów. Wzięły w nich udział 43 oficyny z całej Polski, w tym duża grupa wydawców akademickich. Wśród wystawców było wiele renomowanych wydawnictw, m.in.: PWN, PIW, Arkady, Wiedza Powszechna, Wydawnictwo Literackie, Wydawnictwa Techniczno-Naukowe, Wydawnictwo Komunikacji i Łączności, Polskie Wydawnictwo Ekonomiczne, Wydawnictwo Sejmowe, Wydawnictwo C.H. Beck. Osiągnięty został zasadniczy cel, jakim było przedstawienie i przybliżenie środowiskom akademickim, oświatowym, księgarzom, bibliotekarzom i hurtownikom rozległej oferty z zakresu szeroko pojętej książki naukowej i dydaktycznej, ważne ze względu na brak systemu sprawnej informacji o tego typu publikacjach i komercyjne nastawienie większości księgarń, zainteresowanych książką szybko się sprzedającą.

Akceptacja środowiska i sukces targów zachęciły do ich kontynuowania. Od 14 do 17 października 1998 roku odbywały się II PDKN, które zgromadziły już 60 wystawców. Towarzyszyły one Poznańskim Dniom Nauki i Sztuki. Każdorazowo podczas targów organizowano konferencje poświęcone tematyce interesującej wydawców, z udziałem specjalistów, autorytetów naukowych i środowiska edytorskiego, promocje nowości czy spotkania z autorami na stoiskach, połączone z podpisywaniem książek. W związku z bardzo dużym zainteresowaniem targami Komitet Organizacyjny - w niezmienionym składzie - przygotował trzecią edycję imprezy. Ze względu na konieczność pozyskania większej powierzchni wystawowej w 1999 roku targi przeniesiono się do Holu Wielkiego CK Zamek,

${ }^{20}$ Wszystkie dane dotyczące Poznańskich Dni Książki Naukowej zaczerpnięto z dokumentacji archiwalnej dostępnej w Wydawnictwie. 
którego dyrektor Marek Raczak wyraził zgodę na wejście do Komitetu Organizacyjnego. Z roku na rok zwiększała się liczba wystawców w 2003 roku było ich ponad 80, a w 2004 roku w VIII PDKN uczestniczyła rekordowa liczba wydawców - ponad 90.

Jubileuszowe X PDKN odbywały się od 28 do 30 września 2006 roku. Dużym zainteresowaniem gości cieszyły się prezentacje internetowego systemu informatycznego oraz druku cyfrowego. Ponadto po raz pierwszy zorganizowano stoisko zbiorcze pod patronatem SWSW, gdzie swoje książki wystawiały oficyny akademickie. Kolejne edycje PDKN znalazły trwałe miejsce w kalendarzu imprez targowych. Zmienił się skład Komitetu Organizacyjnego - do grona członków dołączyli dyrektor Biblioteki Uniwersyteckiej dr Artur Jazdon (2003) i reprezentująca SWSW Anna Zielińska-Krybus (2008). Wkrótce impreza zyskała dodatkowe atuty $\mathrm{w}$ postaci honorowego patronatu ministra nauki i szkolnictwa wyższego oraz głównej nagrody - Pucharu Ministra w Konkursie na Najlepszą Książkę Akademicką. Od 2007 roku odbywa się również Konkurs SWSW im. ks. Edwarda Pudełki na Najlepszy Podręcznik Akademicki, w którym startuje wiele oficyn uczelnianych.

Po wielu latach korzystania z gościny w CK Zamek impreza targowa powróciła na teren Uniwersytetu - od 2009 roku miejscem ekspozycji jest

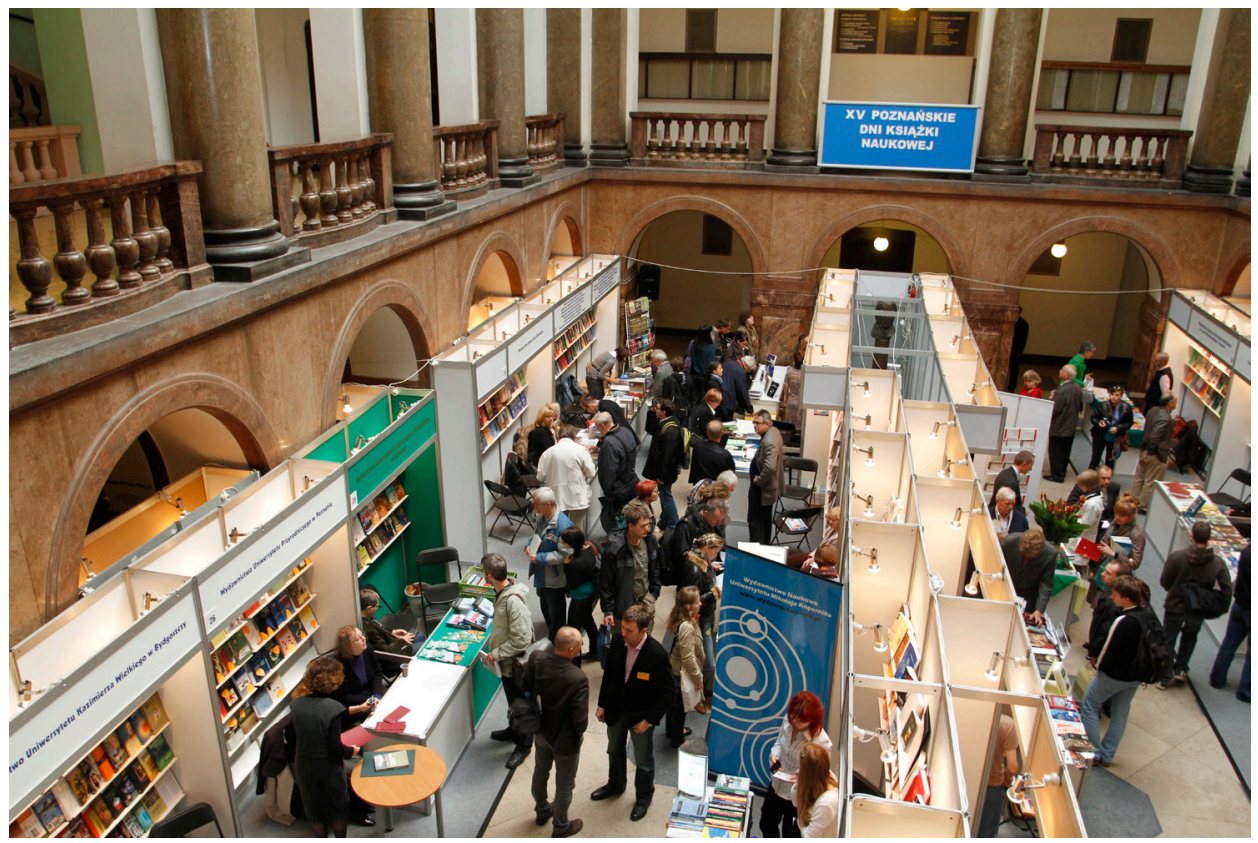

Fot. 2. Jubileuszowe XV Poznańskie Dni Książki Naukowej w pięknym holu Collegium Maius. Fot. Maciej Męczyński 


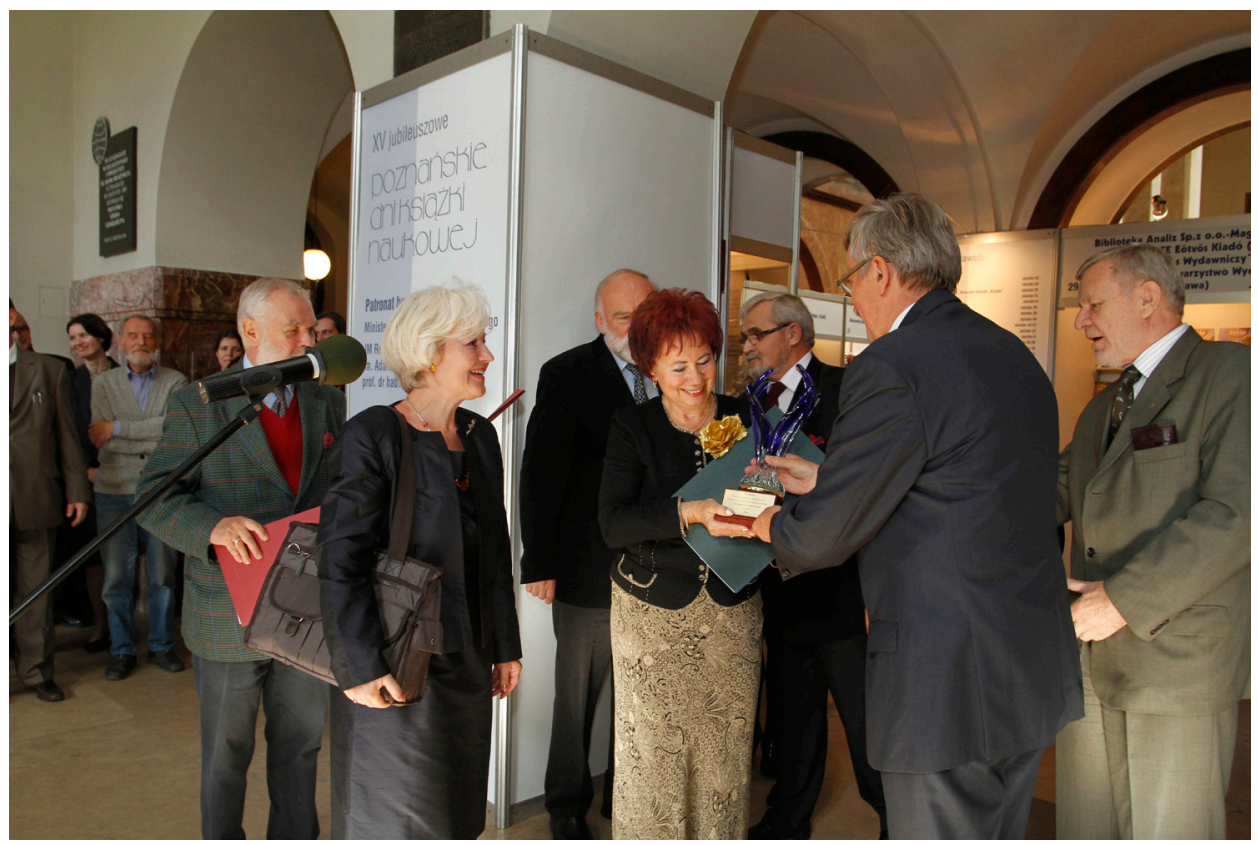

Fot. 3. XV Jubileuszowe PDKN (12 października 2011 roku) - rektor UAM prof. Bronisław Marciniak przekazuje ufundowany przez siebie puchar dyrektor Wydawnictwa Iwonie Wegner-Maruszewskiej. Fot. Maciej Męczyński

znów piękny hol Collegium Maius. Tutaj także świętowaliśmy XV Jubileuszowe Poznańskie Dni Książki Naukowej od 12 do 14 października 2011 roku, w których uczestniczyło 65 wydawnictw (fot. 2, 3). Specjalnie $\mathrm{z}$ tej okazji JM Rektor UAM prof. Bronisław Marciniak ufundował puchar dla najlepszej książki autora z Uniwersytetu im. Adama Mickiewicza.

Pół wieku wydawania trudnych naukowych publikacji, podręczników i skryptów z różnych dziedzin wiedzy, specjalistycznych czasopism (także obcojęzycznych) odcisnęło trwały ślad w historii Uniwersytetu, a historia Uniwersytetu im. Adama Mickiewicza znalazła swe miejsce w licznych książkach, które ukazały się w Wydawnictwie Naukowym UAM. Uwieńczeniem dotychczasowej działalności oficyny była imponująca przekrojowa wystawa "50 lat Wydawnictwa Naukowego UAM" pod honorowym patronatem JM Rektora prof. Bronisława Marciniaka, zorganizowana $w$ Bibliotece Uniwersyteckiej w ramach IX edycji Tygodnia Bibliotek (fot. 4). Uroczyste otwarcie wystawy odbyło się 11 maja 2012 roku. Uczestniczyli w nim m.in.: dyrektor Biblioteki Uniwersyteckiej dr Artur Jazdon, prorektor UAM prof. Zbigniew Pilarczyk, wiceprezydent m. Poznania Tomasz Kayser, kurator wystawy, długoletnia dyrektor Wydawnictwa Iwona Wegner-Maruszewska, liczne grono gości 
z branży wydawniczej, księgarskiej i bibliotekarskiej oraz pracowników Wydawnictwa i miłośników książki. Na ekspozycji znalazło się prawie 1000 publikacji zarówno archiwalnych, jak i najnowszych, ułożonych tematycznie. Wystawę uzupełniały liczne zdjęcia, plakaty, ciekawe graficznie okładki książek. W poszczególnych gablotach zwiedzający mogli zobaczyć: wydawnictwa ciągłe i czasopisma, reprezentatywne podręczniki i skrypty oraz pomoce dydaktyczne, różnego typu słowniki, książki do nauki języków obcych, obcojęzyczne wersje tekstów polskich oraz przekłady publikacji zagranicznych dokumentujące współpracę międzynarodowa, monografie naukowe, które ukazały się w ponad 50 seriach tematycznych, wspaniałe, często monumentalne księgi pamiątkowe dla zasłużonych profesorów naszej uczelni, publikacje jubileuszowe związane z Uniwersytetem, wydawnictwa dokumentujące działalność UAM, np. kroniki, albumy czy inne druki upamiętniające ważne wydarzenia (m.in. doktoraty honoris causa, wykłady inauguracyjne), zachwycające urodą edytorską liczne książki nagrodzone w konkursach branżowych, wreszcie dokumentację fotograficzną przypominającą historię Wydawnictwa i jego zespół oraz organizowane od 1997 roku targi - Poznańskie Dni Książki Naukowej.

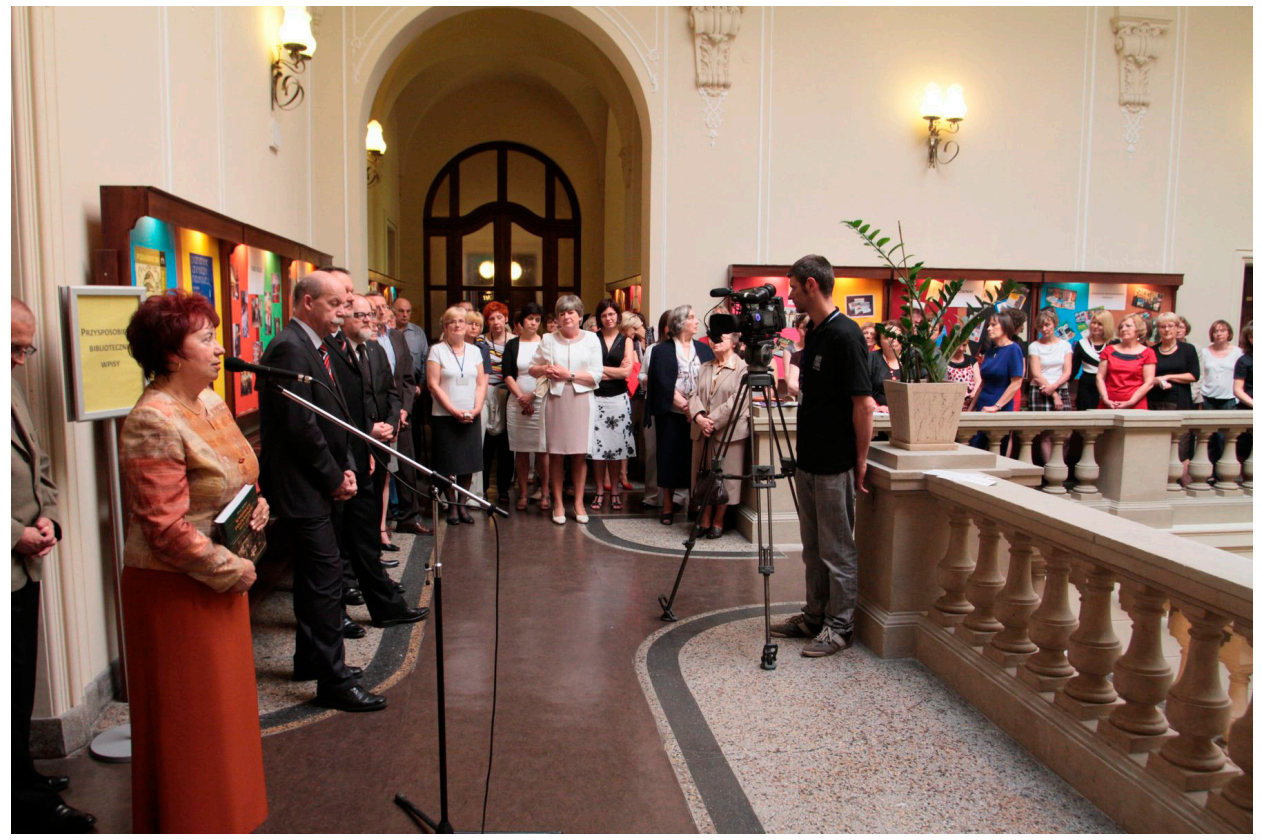

Fot. 4. Biblioteka Uniwersytecka - otwarcie wystawy „50 lat Wydawnictwa Naukowego UAM" (11 maja 2012 roku). Fot. Maciej Męczyński 


\section{Załącznik 1}

\section{Rola i zadania Wydawnictwa}

\section{Rola Wydawnictwa}

1. Wydawnictwo jako jednostka ogólnouczelniana służy społeczności akademickiej, zarówno pracownikom naukowym, jak i studentom.

2. Wydawnictwo jest placówką integrującą przedstawicieli wszystkich uprawianych na Uczelni dyscyplin naukowych, odzwierciedla jej universum w tematycznej różnorodności publikacji.

3. Wydawnictwo uczestniczy - poprzez fachowość i staranność edytorską publikacji - w tworzeniu dobrego wizerunku Uczelni i promowaniu jej osiągnięć.

4. Wydawnictwo reprezentuje środowisko uniwersyteckie poprzez jego publikacje.

\section{Zadania Wydawnictwa}

Podstawowymi zadaniami Wydawnictwa są:

1. Utrwalanie i promowanie dorobku naukowego pracowników Uczelni poprzez publikowanie monografii naukowych (przede wszystkim tak istotnych dla rozwoju kadry rozpraw habilitacyjnych) oraz specjalistycznych czasopism. Umożliwienie publikowania książek niskonakładowych, wąskotematycznych.

2. Propagowanie dokonań naukowych Uczelni za granicą (wydawanie prac w językach obcych, zaopatrywanie monografii i czasopism polskojęzycznych w abstrakty i obszerniejsze streszczenia, co sprzyja wymianie prowadzonej przez Bibliotekę Uniwersytecka, udział w wystawach zagranicznych).

3. Obsługiwanie procesu dydaktycznego poprzez publikowanie podręczników, skryptów, słowników i innych książek służących kształceniu - w starannie i trafnie przemyślanej formie edytorskiej.

4. Dokumentowanie działalności Uczelni (kroniki, wykłady inauguracyjne, doktoraty honoris causa, materiały informacyjne).

5. Upowszechnianie publikacji poprzez sprzedaż bezpośrednią, wysyłkową i w księgarniach naukowych (także w księgarni PWN).

6. Docieranie do odbiorców poprzez różne formy informacji wydawniczej (w tym internetowej), udział w targach książki, wystawach i innych imprezach promocyjnych.

7. Popularyzowanie literatury naukowej i dydaktycznej poprzez samodzielne organizowanie targów książki akademickiej i pokrewnej, spotkań autorskich, promocji itp.

Do zadań szczegółowych Wydawnictwa należą m.in.:

- dbałość o odpowiedzialne, fachowe i jak najstaranniejsze opracowanie redakcyjne, techniczne oraz szatę graficzną publikacji; 
- twórcza współpraca z autorami, przebiegająca zarazem z poszanowaniem ich indywidualności i uwzględnieniem specyfiki dyscyplin;

- szlifowanie pisarskiego warsztatu młodych Autorów, ułatwianie debiutu naukowego;

- dążenie do terminowości i skracania cyklu wydawniczego, a tym samym ograniczania kosztów;

- sukcesywne konstruowanie planu wydawniczego, zapewnianie bazy działania, pozyskiwanie tytułów;

- kształcenie praktykantów, udział w edukacji edytorskiej;

- harmonijne łączenie indywidualnego wysiłku pracowników z poczuciem funkcjonowania w zespole, zespołowego postrzegania procesu powstawania książki;

- obserwowanie tendencji w zakresie kształtowania książki akademickiej oraz wymogów rynku;

- wymiana doświadczeń z innymi wydawnictwami szkół wyższych poprzez udział w targach, konferencjach, wystawach, merytorycznych spotkaniach środowiskowych.

\section{Załącznik 2}

Serie wydawnicze

Akustyka

Antropologia

Archeologia

Astronomia

Badania Interdyscyplinarne

Biologia

Chemia

Doktorzy Honoris Causa

Dzieje UAM

Etnografia

Etnologia i Antropologia Kulturowa

Filmoznawcza

Filologia Angielska

Filologia Bałtycka

Filologia Germańska

Filologia Klasyczna

Filologia Polska

Filologia Romańska

Filologia Rosyjska

Filologia Skandynawska

Filologia Słowiańska
Filozofia i Logika

Fizyka

Fontes Historiae Antiquae

Geografia

Geologia

Historia

Historia Sztuki

Humanistyka i Płeć

Język Kultura Komunikacja

Językoznawstwo

Językoznawstwo Komputerowe

Językoznawstwo Stosowane

Klasyka Kina

Kulturoznawstwo

Laographica Slavica et Balcanensia

Lingwistyka Komputerowa

Literaturoznawstwo Porównawcze

Matematyka

Muzykologia

Na pograniczu chemii i biologii

Nauki Ekonomiczne 
Nauki Medyczne

Nauki Polityczne

Nauki Teologiczne

Orientalistyka

Pedagogika

Prace Biblioteki Uniwersyteckiej

Prace Ogrodu Botanicznego UAM

Prace Ośrodka Metodycznego

Prawo
Psychologia

Psychologia i Pedagogika

Rhomaioi

Socjologia

Technologia Kształcenia

Turystyka i Rekreacja. Studia i Prace

Wykłady Inauguracyjne

Zoologia

\section{Załącznik 3}

Wydawnictwa ciągłe (czasopisma)

Acta Physicae Superficierum

Acta Quaternaria

Artium Quaestiones

Balcanica Posnaniensia. Acta et Studia

Concepts and Methods in Geography

Człowiek i Społeczeństwo

Facultatis Chemiae Universitatis Studiorum Mickiewiczianae Posnanensis

Fenomenologia

Folia Praehistorica Posnaniensia

Folia Scandinavica Posnaniensia

Functiones et Approximatio Commentarii Mathematici

Geologos

Glottodidactica

Hispanica Posnaniensia

Images

Interdisciplinary Studies in Musicology

Laographica Slavica et Balcanensia

Linguistic and Oriental Studies from Poznań

Listy Biometryczne

Lituano-Slavica Posnaniensia. Studia Historica

Naukowe Zeszyty Studenckie

Neodidagmata

Polish Journal for American Studies

Polish-AngloSaxon Studies

Poznań Literary Papers

Poznańskie Studia Polonistyczne. Seria Językoznawcza

Poznańskie Studia Polonistyczne. Seria Literacka

Poznańskie Studia z Filozofii Humanistyki

Prawny i Ekonomiczny Przegląd Prawa Gospodarczego 
Przegląd Prawa Rolnego

Przestrzenie Teorii

Quaestiones Geographicae

Quaestiones Geographicae, Series A, Physical Geography

Quaestiones Geographicae, Series B, Human Geography and Spatial Management

Roczniki Socjologii Rodziny

Ruch Prawniczy, Ekonomiczny i Socjologiczny

Sprawy Wschodnie

Studia Edukacyjne

Studia Germanica Posnaniensia

Studia Historiae Oeconomicae

Studia Historica Slavo-Germanica

Studia Lednickie

Studia Linguistica Polono-Meridianoslavica

Studia Metodologiczne

Studia Phonetica Posnaniensia. An International Journal for Linguistic Phonetics Studia Romanica Posnaniensia

Studia Rossica Posnaniensia

Symbolae Philologorum Posnaniensium Graecae et Latinae

Variability and Evolution

Zeszyty Naukowe Centrum Badań im. Edyty Stein

\title{
Załącznik 4
}

\author{
Książki Wydawnictwa Naukowego UAM \\ nagrodzone w latach 1994-2012 \\ (w układzie alfabetycznym)
}

Balcanica Posnaniensia. Acta et Studia (wydawnictwo seryjne)

- Nagroda im. prof. Jerzego Skowronka (Warszawa 2000)

Edward Balcerzan, Tłumaczenie jako „wojna światów”. W kręgu translatologii i komparatystyki

- Nominacja do Nagrody w Konkursie im. Jana Długosza (XIV Targi Książki w Krakowie 2010)

Wrócisława Bergandy, Od alchemii do chemii kwantowej

- Wyróżnienie specjalne w Konkursie na Najtrafniejszą Szatę Edytorską Książki Naukowej (IV Wrocławskie Targi Książki Naukowej 1998)

Jerzy Borowczyk, Rekonstrukcja procesu filomatów i filaretów 1823-1824

- Nagroda Klio II st. w kategorii autorskiej (XI Targi Książki Historycznej w Warszawie 2001) 
Mariusz Bryl, Suwerenność dyscypliny. Polemiczna historia historii sztuki od 1970 roku - Nominacja do Nagrody im. Jana Długosza (XIII Targi Książki w Krakowie 2009)

Jacek Brzozowski, Zbigniew Przychodniak (oprac.), Juliusz Słowacki, Poematy. Nowe wydanie krytyczne

- Nagroda Główna w Konkursie na Najlepszy Podręcznik i Skrypt Akademicki (XIV Targi Książki w Krakowie 2010)

Jacek Brzozowski, Zbigniew Przychodniak (oprac.), Juliusz Słowacki, Wiersze. Nowe wydanie krytyczne

- Nagroda Stowarzyszenia Bibliotekarzy Polskich za Najlepszą Książkę Akademicką (XII Krajowe Targi Książki Akademickiej ATENA w Warszawie 2005)

- Wyróżnienie „Książka Wiosny 2006” (Poznański Przegląd Nowości Wydawniczych)

- Nagroda Ministra Nauki i Szkolnictwa Wyższego 2006 - nagroda autorska

Andrzej Burewicz, Hanna Gulińska, Dydaktyka chemii

- Nagroda Specjalna Ministra Edukacji Narodowej w Konkursie na Najlepszą Książkę Akademicką (I Krajowe Targi Książki Akademickiej ATENA w Warszawie 1994)

Adam Choiński, Katalog jezior Polski

- Nagroda w Konkursie na Najlepszy Podręcznik Akademicki im. ks. Edwarda Pudełki (XI Poznańskie Dni Książki Naukowej 2007)

Adam Choiński, Limnologia fizyczna Polski

- Nominacja w Konkursie na Najlepszy Podręcznik i Skrypt Akademicki (XII Targi Książki w Krakowie 2008)

Florian Domka, Chemiczne metody analizy ilościowej

- I Nagroda w Konkursie na Najtrafniejszą Szatę Edytorską Książki Naukowej (I Wrocławskie Targi Książki Naukowej 1995)

Sylwester Dworacki (tłum. z jęz. greckiego, wstęp oraz przypisy), Heliodor, Opowieść etiopska o Theagenesie i Chariklei

- Wyróżnienie w Konkursie na Najtrafniejszą Szatę Edytorską Książki Naukowej (VII Wrocławskie Targi Książki Naukowej 2001)

Grzegorz Dziamski, Przełom konceptualny i jego wptyw na praktyke $i$ teorie sztuki

- Nominacja do Nagrody im. Jana Długosza (XV Targi Książki w Krakowie 2011)

Jerzy Fiećko, Rosja Krasińskiego. Rzecz o nieprzejednaniu

- Nagroda Klio II st. w kategorii monografii naukowej (XV Targi Książki Historycznej w Warszawie 2005)

- Wyróżnienie „Książka Wiosny 2005” (Poznański Przegląd Nowości Wydawniczych)

- Nagroda Ministra Nauki i Szkolnictwa Wyższego 2006 - nagroda autorska

Aneta Grodecka, Wiersze o obrazach. Studium z dziejów ekfrazy

- Nominacja do Nagrody w Konkursie na Najlepszy Podręcznik i Skrypt Akademicki (XIII Targi Książki w Krakowie 2009) 
- Wyróżnienie w Konkursie na Najlepszy Podręcznik Akademicki im.

ks. Edwarda Pudełki (XIII Poznańskie Dni Książki Naukowej 2009)

Ewa Guderian-Czaplińska, Teatralna Arkadia. Poznańskie teatry dramatyczne 1918-1939

- Nagroda „Książka Wiosny 2004” (Poznański Przegląd Nowości Wydawniczych)

- Wyróżnienie w IV edycji Konkursu Biblioteki Kórnickiej na Najlepszą Publikację o Poznaniu i Wielkopolsce (Poznań 2005)

Małgorzata Hendrykowska, Smosarska

- Nominacja do Nagrody w Konkursie im. Jana Długosza (XII Targi Książki w Krakowie 2008)

Małgorzata Hendrykowska, Marek Hendrykowski (red.), Klasyka Kina

- Wyróżnienie w Konkursie na Najlepszą Książkę Akademicką i Naukową ACADEMIA w kategorii Seria Wydawnicza (III Targi Książki Akademickiej i Naukowej ACADEMIA 2009)

Małgorzata Hendrykowska, Marek Hendrykowski (red.), Przemoc na ekranie

- Wyróżnienie „Książka Jesieni 2001” (Poznański Przegląd Nowości Wydawniczych)

Małgorzata Jankowska, Sergiusz Niziński (red.), Fenomen pięknego życia

- Wyróżnienie Stowarzyszenia Wydawców Katolickich w konkursie Feniks 2012 w kategorii Seria Wydawnicza (XVIII Targi Wydawców Katolickich w Warszawie 2012)

Mikołaj Jazdon, Kino dokumentalne Kazimierza Karabasza

- Wyróżnienie w Konkursie Ministra Nauki i Szkolnictwa Wyższego na Najlepszą Książkę Akademicką (XIV Poznańskie Dni Książki Naukowej 2010)

Urszula Jorasz, Stuchając, czyli kontredans akustyki ze sztuka

- Wyróżnienie w Konkursie na Najlepszy Podręcznik Akademicki im. ks. Edwarda Pudełki (XIV Poznańskie Dni Książki Naukowej 2010)

Piotr Juszkiewicz, Od rozkoszy historiozofii do gry w nic. Polska krytyka artystyczna czasu odwilży

- Nagroda Artystyczna im. Jerzego Stajudy (2006)

Tomasz Kaczmarek, Struktury terytorialno-administracyjne i ich reformy w krajach europejskich

- Nagroda Ministra Nauki i Szkolnictwa Wyższego (2006)

Piotr Kłysz, Janusz Skoczylas, Oblicze naszej planety - geologia i geomorfologia w zarysie

- Wyróżnienie w Konkursie na Najlepszą Książkę Akademicką (X Krajowe Targi Książki Akademickiej ATENA w Warszawie 2003)

- Wyróżnienie w Konkursie na Najtrafniejszą Szatę Edytorską Książki Naukowej (IX Wrocławskie Targi Książki Naukowej 2003)

Waldemar Kuligowski, Miłość na Zachodzie. Historia antropologiczna

- Nagroda „Książka Jesieni 2004” (Poznański Przegląd Nowości Wydawniczych) 
Krzysztof Kurek, Teatr i miasto. Historia sceny polskiej w Poznaniu w latach 1782-1849

- Nagroda Główna w Konkursie Ministra Nauki i Szkolnictwa Wyższego na Najlepszą Książkę Akademicką (XIII Poznańskie Dni Książki Naukowej 2009)

Czesław Łuczak, Polska i Polacy w drugiej wojnie światowej

- Nagroda Historyczna „Polityki” (1994)

Aleksander Łukasiewicz (red.), Ogród Botaniczny Uniwersytetu im. Adama Mickiewicza w Poznaniu 1925-2000

- Wyróżnienie „Książka Lata 2000” (Poznański Przegląd Nowości Wydawniczych)

Dariusz Matelski, Mniejszość niemiecka w Wielkopolsce w latach 1919-1939

- Nagroda Klio w kategorii monografii naukowej (VII Targi Książki Historycznej w Warszawie 1997)

Jerzy Moczko, Lucyna Kramer, Cyfrowe metody przetwarzania sygnałów biomedycznych

- Wyróżnienie w Konkursie na Najlepszą Książkę Akademicką (VIII Krajowe Targi Książki ATENA w Warszawie 2001)

Vesna Mojsova Čepiševska, Lech Miodyński, Bogusław Zieliński (red.), Żeglarze pamięci. Antologia współczesnej literatury macedońskiej

- Wyróżnienie w Konkursie na Najlepszy Podręcznik Akademicki im. ks. Edwarda Pudełki (XIV Poznańskie Dni Książki Naukowej 2010)

Radosław Okulicz-Kozaryn, Litwin wśród spadkobierców Króla-Ducha. Twórczość Čiurlionisa wobec Młodej Polski

- Wyróżnienie w Konkursie Ministra Nauki i Szkolnictwa Wyższego na Najlepszą Książkę Akademicką 2007 (XI Poznańskie Dni Książki Naukowej)

- Nominacja do Nagrody ACADEMIA w Konkursie na Najlepszą Książkę Akademicką i Naukową ACADEMIA (I Targi Książki Akademickiej i Naukowej ACADEMIA 2007)

Wiesław Olszewski, Chiny. Zarys kultury

- Nagroda w Konkursie na Najtrafniejszą Szatę Edytorską Książki Naukowej (X Wrocławskie Targi Książki Naukowej 2004)

- Nominacja do Nagrody na Najlepszy Podręcznik i Skrypt Akademicki (VIII Targi Książki w Krakowie)

- Nagroda Główna w Konkursie na Najlepszą Książkę Akademicką (XI Krajowe Targi Książki Akademickiej ATENA w Warszawie 2004)

Wiesław Olszewski, Cmentarze na stokach poznańskiej Cytadeli

- Wyróżnienie w Konkursie Ministra Nauki i Szkolnictwa Wyższego na Najlepszą Książkę Akademicką (XII Poznańskie Dni Książki Naukowej 2008)

- Nagroda im. Józefa Łukaszewicza (Biblioteki Raczyńskich, Posnaniana 2008)

Krystyna Pieniążek-Marković, Goran Rem, Bogusław Zieliński (oprac.), Widzieć Chorwacje. Panorama literatury i kultury chorwackiej 1990-2005

- Nagroda im. Jerzego Skowronka (Warszawa 2006) 
- Wyróżnienie w Konkursie na Najlepszy Podręcznik i Skrypt Akademicki (X Targi Książki w Krakowie 2006)

Ewa Piotrowska, Bernard Piotrowski, Święta Brygida Szwedzka na tle swoich czasów

- Nagroda w Konkursie na Najlepszy Podręcznik i Skrypt Akademicki (X Targi Książki w Krakowie 2006)

Grzegorz Raubo, "Ludzie się na górne zapatruja obroty”. Astronomiczne konteksty literatury polskiego baroku

- Wyróżnienie w Konkursie o Puchar JM Rektora Uniwersytetu im. Adama Mickiewicza, w Konkursie na Najlepszą Książkę Akademicką (XV Poznańskie Dni Książki Naukowej 2011)

Andrzej Rozwadowski, Obrazy z przeszłości. Hermeneutyka sztuki naskalnej

- Wyróżnienie w Konkursie na Najtrafniejszą Szatę Edytorską Książki Naukowej (XV Wrocławskie Targi Książki Naukowej 2009)

- Nominacja do Nagrody w Konkursie im. Jana Długosza (XIV Targi Książki w Krakowie 2010)

Alicja Sakaguchi, Język - mistyka - proroctwo. Od doświadczenia do wysłowienia

- Nagroda Główna, Puchar JM Rektora Uniwersytetu im. Adama Mickiewicza w Konkursie na Najlepszą Książkę Akademicką (XV Poznańskie Dni Książki Naukowej)

- Wyróżnienie Stowarzyszenia Wydawców Katolickich w konkursie Feniks 2012 w kategorii Myśl Humanistyczna (XVIII Targi Wydawców Katolickich w Warszawie 2012)

Dariusz Sikorski, Kościót w Polsce za Mieszka I i Bolesława Chrobrego

- Nagroda Klio III st. w kategorii autorskiej (XX Targi Książki Historycznej w Warszawie 2011)

Krzysztof Trybuś, Pamięć romantyzmu. Studia nie tylko z przeszłości

- Wyróżnienie JM Rektora Uniwersytetu im. Adama Mickiewicza w Konkursie na Najlepszą Książkę Akademicką (XV Poznańskie Dni Książki Naukowej 2011)

Alojzy Woś, Klimat Polski w II połowie XX wieku

- Nagroda Główna, Puchar Ministra Nauki i Szkolnictwa Wyższego w Konkursie na Najlepszy Podręcznik i Skrypt Akademicki (XV Targi Książki w Krakowie 2011)

- Wyróżnienie w Konkursie na Najtrafniejszą Szatę Edytorską (XVII Wrocławskie Targi Książki Naukowej 2011)

Szymon Wróbel, Władza i rozum. Stadia rozwojowe krytycznej teorii społecznej

- Nominacja do Paszportu „Polityki” (2003)

Zygmunt Zagórski i in., Nazewnictwo geograficzne Poznania

- Nagroda im. Józefa Łukaszewicza (Biblioteki Raczyńskich, Posnaniana 2009) 


\title{
Half a century has already passed... Foundation and activity of the Adam Mickiewicz University Press
}

\begin{abstract}
Aвstract. Established in 1962, Adam Mickiewicz University Press is a department of one of the major universities in Poland. It is one of the oldest university presses in Poland being at the Adam Mickiewicz University which is one of the major universities in Poland. The University Press, which celebrates its fifty years in 2012, has been publishing scientific books such as monographs, collected works, series of books on a variety of subjects, a number of scientific journals and the like. Its annual output is about 130 books on the average.

Adam Mickiewicz University Press cooperates with a number of publishing houses at home and abroad. Over its 50 years' existence it has cooperated with such distinguished publishers as Cambridge University Press, John Benjamins, Eburon (the Netherlands), Mouton, and Elsevier. to mention a few. It has exchanged, bought and sold permissions for publication and translation of many scientific books and papers. Some permissions are given and obtained free of charge. Apart from authors coming from our University, we have also published scientific works by authors from other universities in Poznań and Poland as well as from other countries. Many Polish and foreign authors outside of the University have decided to publish their works at our University Press due to its excellent editorial work and artwork.

Thus, Adam Mickiewicz University Press has exhibited its books at home and abroadcities where and has received a number of awards and prizes for the quality of its publications.
\end{abstract}

Key Words: Wydawnictwo Naukowe UAM (Adam Mickiewicz University Press), Poznańskie Dni Książki Naukowej (Poznan Scientific Book Days), scientific book, series editions, academic textbook, book fairs, book promotion, editorship education. 
